UDC 551.510.42

N. S. Miatselskaya ${ }^{1}$, V. P. Kabashnikov ${ }^{1}$, A. V. Norko ${ }^{1}$, A. P. Chaikovsky ${ }^{1}$, A. I. Bril ${ }^{1}$, G. P. Milinevsky ${ }^{2,3,4}$, V. O. Danylevsky ${ }^{2}$

${ }^{1}$ B. I. Stepanov Institute of Physics of the National Academy of Sciences of Belarus, Minsk, Belarus

${ }^{2}$ Taras Shevchenko National University of Kyiv, Kyiv, Ukraine

${ }^{3}$ Main Astronomical Observatory, National Academy of Sciences of Ukraine, Kyiv, Ukraine

${ }^{4}$ Jilin University, International Center of Future Sciences, Changchun, China

\title{
ATMOSPHERE AEROSOL MODELING BY GEOS-CHEM FOR THE AEROSOL-UA SPACE PROJECT VALIDATION
}

\begin{abstract}
We used a global chemical transport model GEOS-Chem to compute monthly mean fine, coarse, and total aerosol volume concentration for Minsk and Kyiv in the period from 2010 to 2015. We compared results of the model simulation with sun-photometer observations at the ground-based AERONET network sites. We obtained that the aerosol volume concentrations retrieved from observations are in reasonably good agreement with model-simulated ones. However, the agreement is not good enough for the validation of the satellite measurements in the future space mission Aerosol-UA by the GEOS-Chem model simulation. To improve the accuracy of estimating the spatial-temporal distribution of the aerosol volume concentration we decided to apply the optimal interpolation method for assimilating AERONET data in GEOS-Chem model. The temporal correlation function for fine aerosol volume concentration is obtained on the basis of measurements at AERONET Minsk site over the 2002-2015 period and Kyiv site over the 2008-2015 period. We describe the analyzed values of fine aerosol volume concentration at all temporal grid points over the period of 2002 to 2015 for Minsk site and of 2008 to 2015 for Kyiv site, which were determined on the basis of the optimal interpolation method. We propose to use the optimal averaging method for AERONET data on the basis of the temporal optimization interpolation method.
\end{abstract}

Keywords: aerosol, chemical transport GEOS-Chem, model, data assimilation, sun photometer.

\section{INTRODUCTION}

Aerosols are an important component in the Earth's atmosphere. Aerosols cause atmospheric pollution which influence negatively on human health. They affect the radiation balance of the atmosphere, resulting in climate change.

Aerosol distribution in the Earth's atmosphere is studied using measurements from many satellite and ground-based instruments. However, the distribu-

(C) N. S. MIATSELSKAYA, V. P. KABASHNIKOV,

A. V. NORKO, A. P. CHAIKOVSKY, A. I. BRIL,

G. P. MILINEVSKY, V. O. DANYLEVSKY, 2017 tion and properties of atmospheric aerosols are still not sufficiently known because of high spatial and temporal variability of aerosol concentration, sources, and types. To fill a gap, several aerosol space missions are planned [1], and one of them is the Ukrainian project Aerosol-UA [1, 2]. The main objectives of the project are: to monitor the spatial distribution of key characteristics of terrestrial tropospheric and stratospheric aerosols; to provide a comprehensive observational database enabling accurate quantitative estimates of the aerosol contribution to the energy budget of the climate system; quantify the contribution of anthropogenic aerosols to climate and 
ecological processes [1]. The measurements of the intensity and polarization of sunlight scattered by the atmosphere and the Earth's surface are planned to be obtained by using a multi-channel scanning polarimeter ScanPol and wide-angle multispectral imagerpolarimeter MSIP [2].

Data retrieved from the ScanPol and MSIP spaceborne polarimeters measurement are planned to be validated using the methods applied in space born missions [3-5]. One of the methods is use correlative ground-based and satellite data sets (see ex. [4]). The instruments of Aerosol-UA mission will be validated by comparing satellite data with ground-based sun/sky photometer observations from AERONET sites (AErosol RObotic NETwork, http://aeronet. gsfc.nasa.gov, [6-9]). The network consists of about 800 sites located throughout the world. The AERONET inversion algorithm [10] provides information on aerosol properties integrated over the atmospheric column.

However, ground-based observations represent specific point measurements and have limited spatial coverage. Sun photometer measurements are restricted to day-time and cloud-free conditions. Model simulations can be applied to obtain information on aerosol concentration and composition with complete spatial and temporal coverage [11, 12]. The model must provide consistent information for satellite measurements validation.

\section{COMPARISON OF THE MODEL SIMULATION WITH AERONET DATA}

One of the widely used global chemical transport models is GEOS-Chem (see http://acmg.seas.harvard.edu/geos, [13]). GEOS-Chem is a global 3-D chemical transport model driven by assimilated meteorological data from the Goddard Earth Observing System at the NASA Global Modeling Assimilation Office (http://gmao.gsfc.nasa.gov). Meteorological input includes winds, temperature, humidity, convective mass fluxes, cloud properties, surface properties, precipitation, mixed layer depth and other fields. The model uses inventories for fossil fuel, biomass burning, biofuel burning, biogenic, and aerosol emissions. The GEOS-Chem model provides spatial and temporal distribution of atmospheric species concentrations including major aerosol types such as sul- phate, nitrate, ammonium, elemental (black) carbon, organic aerosol, mineral dust, and sea salt.

We compare aerosol volume concentration from the model simulation with observations from AERONET sites for the 2010-2015 period. Volume concentration in $\mu \mathrm{m}^{3} \mu \mathrm{m}^{-2}$ is defined as a total volume of aerosol particles in the atmospheric column divided by the surface area of the atmospheric column cross section. AERONET website (http://aeronet.gsfc. nasa.gov) represents the fine mode VolCon-F (particles radius ranges from 0.05 to $0.6 \mu \mathrm{m}$ ), coarse mode VolCon-C (radius ranges from 0.6 to $15 \mu \mathrm{m}$ ), and total VolCon-T aerosol volume concentrations along with other retrieval products.

To calculate the volume concentration we use the NOx-Ox-hydrocarbon-aerosol GEOS-Chem simulation at $4^{\circ} \times 5^{\circ}$ horizontal resolution with 47 vertical levels up to $80 \mathrm{~km}$ of altitude with GEOS-5 meteorology. The volume concentration of fine mode aerosols is calculated as the sum of the fine mode particles volume concentrations including sulfates, nitrates, ammonium, mineral dust with the effective radius of particles less than $1 \mu \mathrm{m}$, inorganic carbon, organic aerosol, and sea salt with the effective particle radius $<0.5$ $\mu \mathrm{m}$. The volume concentration of coarse mode aerosols is calculated as the sum of the aerosol coarse particles volume concentrations including mineral dust with the effective particle radius $>1 \mu \mathrm{m}$, and sea salt with the effective particle radius $>0.5 \mu \mathrm{m}$. The hygroscopic growth of the hydrophilic particles is taken into account. Hygroscopic growth factor at ambient relative humidity for each aerosol type is provided by the GEOS-Chem simulation. The dry particles density for different aerosol types is taken from [14].

The comparison of the monthly mean fine, coarse and total aerosol volume concentrations measured by sun photometers and simulated by the GEOS-Chem model is shown in Fig. 1 for Minsk and for Kyiv.

The model captures the magnitude and seasonal cycle of the monthly mean fine, coarse and total aerosol volume concentrations. However, the agreement between model results and measurements is not good enough. For example, for the fine aerosols over Minsk, some of the individual discrepancies can reach $0.03-$ $0.04 \mu \mathrm{m}^{3} \mu \mathrm{m}^{-2}$ while the mean measured volume concentration is $0.025 \mu \mathrm{m}^{3} \mu \mathrm{m}^{-2}$ with standard deviation $0.013 \mu \mathrm{m}^{3} \mu \mathrm{m}^{-2}$, and the mean modeled volume con- 

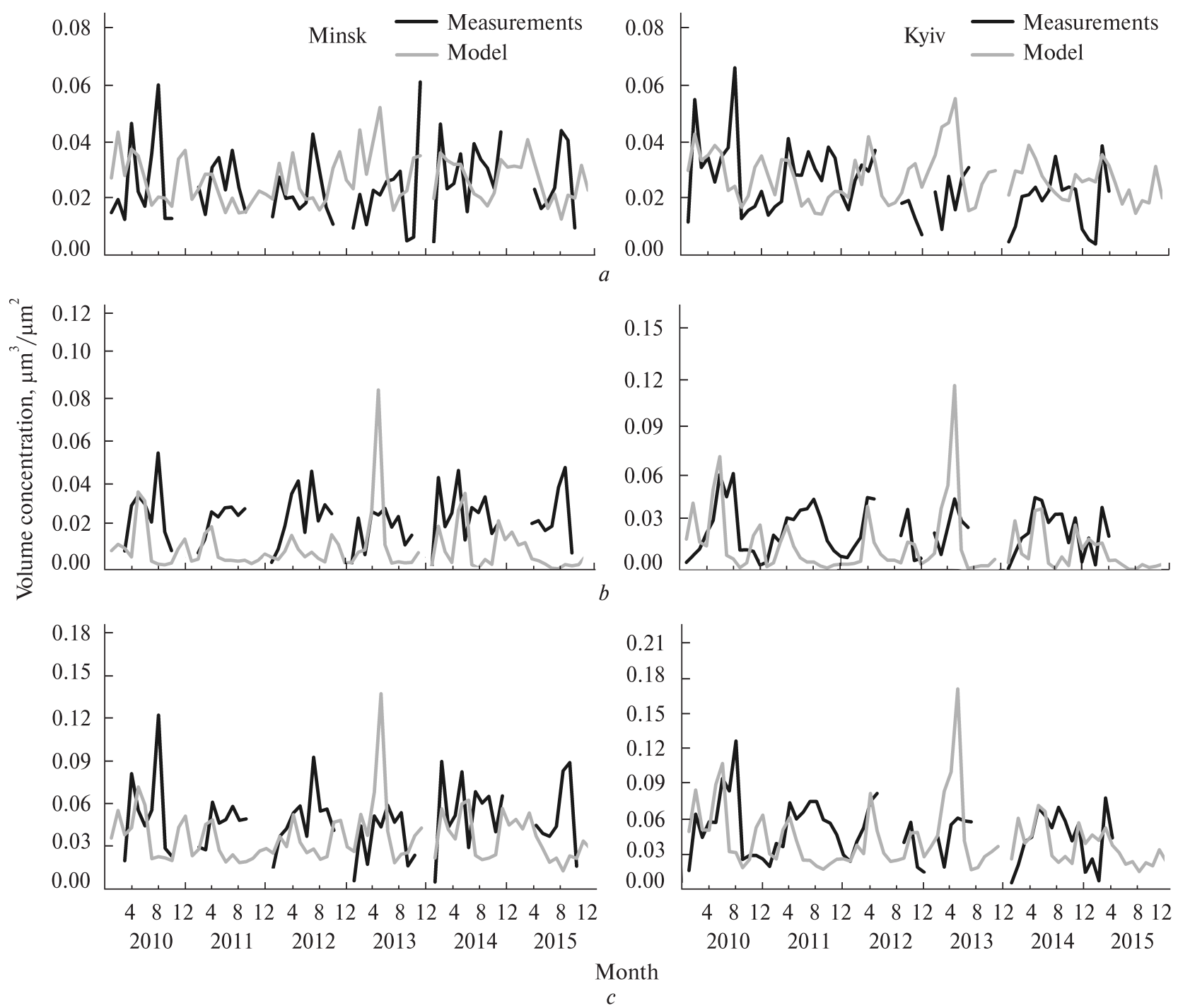

Fig. 1. Monthly mean aerosol volume concentrations measured by sun photometer at Minsk and Kyiv AERONET sites and simulated by the GEOS-Chem model: $a$ - fine mode, $b$ - coarse mode, $c$ - total aerosol

centration is $0.027 \mu \mathrm{m}^{3} \mu \mathrm{m}^{-2}$ with standard deviation $0.008 \mu \mathrm{m}^{3} \mu \mathrm{m}^{-2}$. Therefore, the data simulated by the GEOS-Chem model can be hardly used directly for Aerosol-UA validation. To improve the fidelity of the GEOS-Chem aerosol simulation, the data assimilation methods can be applied.

We plan to use an optimal interpolation technique for AERONET data assimilation to obtain the most likely true estimate of the spatial and temporal distribution of aerosol volume concentration.

\section{DATA ASSIMILATION PROCEDURE}

Data assimilation techniques combine observational data with a background field often consisting of a model forecast in order to produce accurate analyses of the state of the system. The optimal interpolation approach for data assimilation was initially developed for meteorological applications $[15,16]$, and was later applied to air pollution study [17]. 

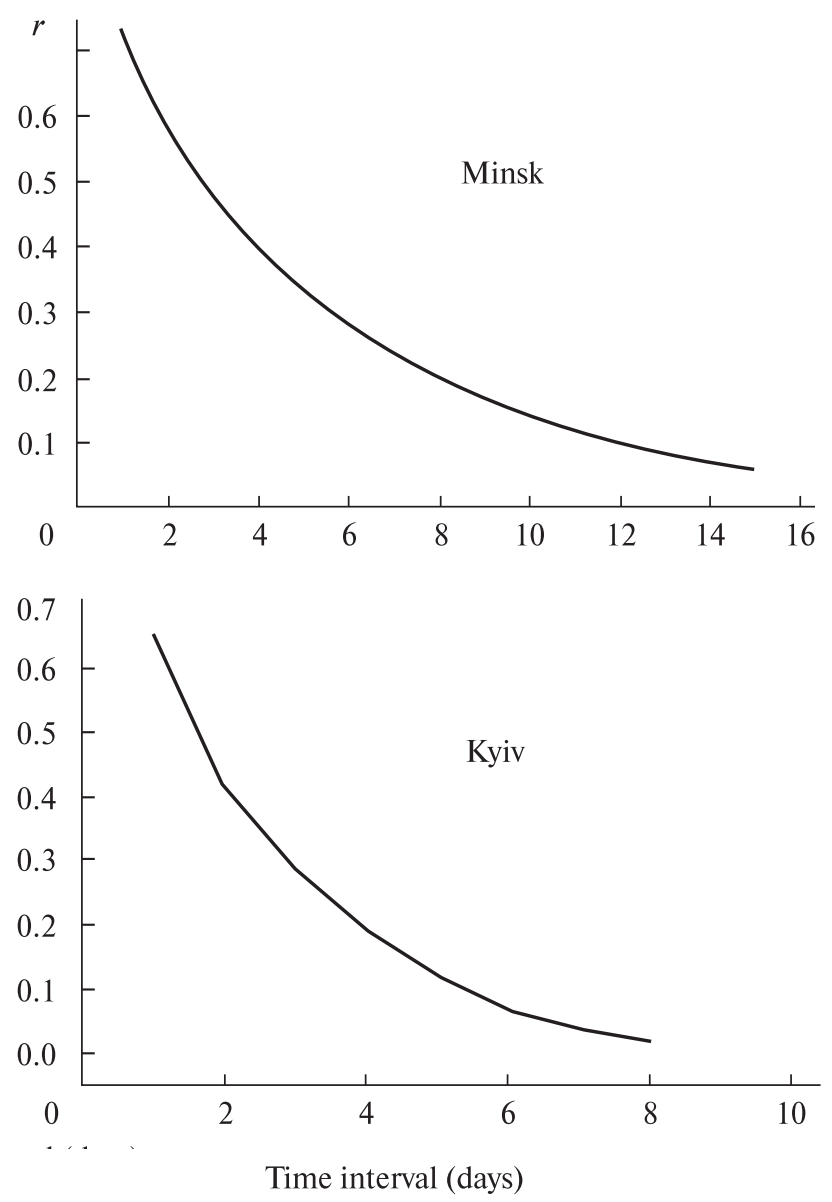

Fig. 2. Time interval dependence of the observation minus background correlation: $a$ - for Minsk site, $b$ - for Kyiv site

In the optimal interpolation scheme, an analysed state is related to the forecast state by the equation:

$$
x^{a}=x B+K\left(y-H\left(x^{b}\right)\right),
$$

where: $x^{a}$ is a vector containing estimated values at regular grid points, $x^{b}$ is a vector containing values of a first guess at regular grid points (background), $\mathrm{y}$ is a vector containing values of observations at the observational points, $K$ is a matrix containing weight coefficients, $H$ is an observation operator (a function from background state space to observation space).

The first guess (background) is based on some $a$ priori information, such as previous analysis, or results of the modeling. Weight coefficients are chosen to minimize the mean-square error in the estimate:

$$
K=G H^{T}\left(H G H^{T}\right)^{-1},
$$

where $G$ is a covariance matrix of deviations of observations from first guess values at the observational points. Weight coefficients can be expressed in terms of errors:

$$
K=P^{b} H^{T}\left(H P^{b} H^{T}+R\right)^{-1},
$$

where $P^{b}$ is a covariance matrix of background errors, $R$ is a covariance matrix of observation errors. A covariance matrix of analysis errors $P^{a}$ can be calculated as

$$
P^{a}=(I-K H) P^{b},
$$

where $I$ is an identity matrix.

\section{APPLICATION OF OPTIMAL INTERPOLATION TO AERONET DATA}

The AERONET sun photometers provide data on aerosol volume concentration only under restrictive observing cloud-free conditions. Therefore, even at the site location, the observations are presented as data series corresponded to cloud-free days, with lack of data at cloudy periods. To fill this gap, we use the temporal optimal interpolation method. We implement the method to data observed at Minsk and Kyiv AERONET sites.

The AERONET data are divided into three quality levels: Level 1.0 for unscreened raw data, Level 1.5 for cloud-screened data, and Level 2.0 for cloudscreened and quality assured data [7, 18]. For calculations we use Level 2.0 data, nevertheless some measured values of the volume concentration look too high mainly due to influence of cloudy condition. We have eliminated the volume concentration values measured at three cases: 10.09.2002 at 7:09:04, 13.09.2002 at 12:08:01, and 30.04.2006 at 04:27:56. Observations always contain some errors; however, we assume here that the measurement data are free of uncertainties.

The covariance matrix $G$ is defined by a correlation function. We assume that correlations between temporal grid points depend on the length of time interval only and do not depend on time itself. In this case the single correlation function can be estimated from observational data with the temporal correlation length adjusted empirically. Observational data of fine aerosol volume concentration at Minsk site over the period of 2002 to 2015 and at Kyiv site over the period $2008-2015$ provide statistical informa- 

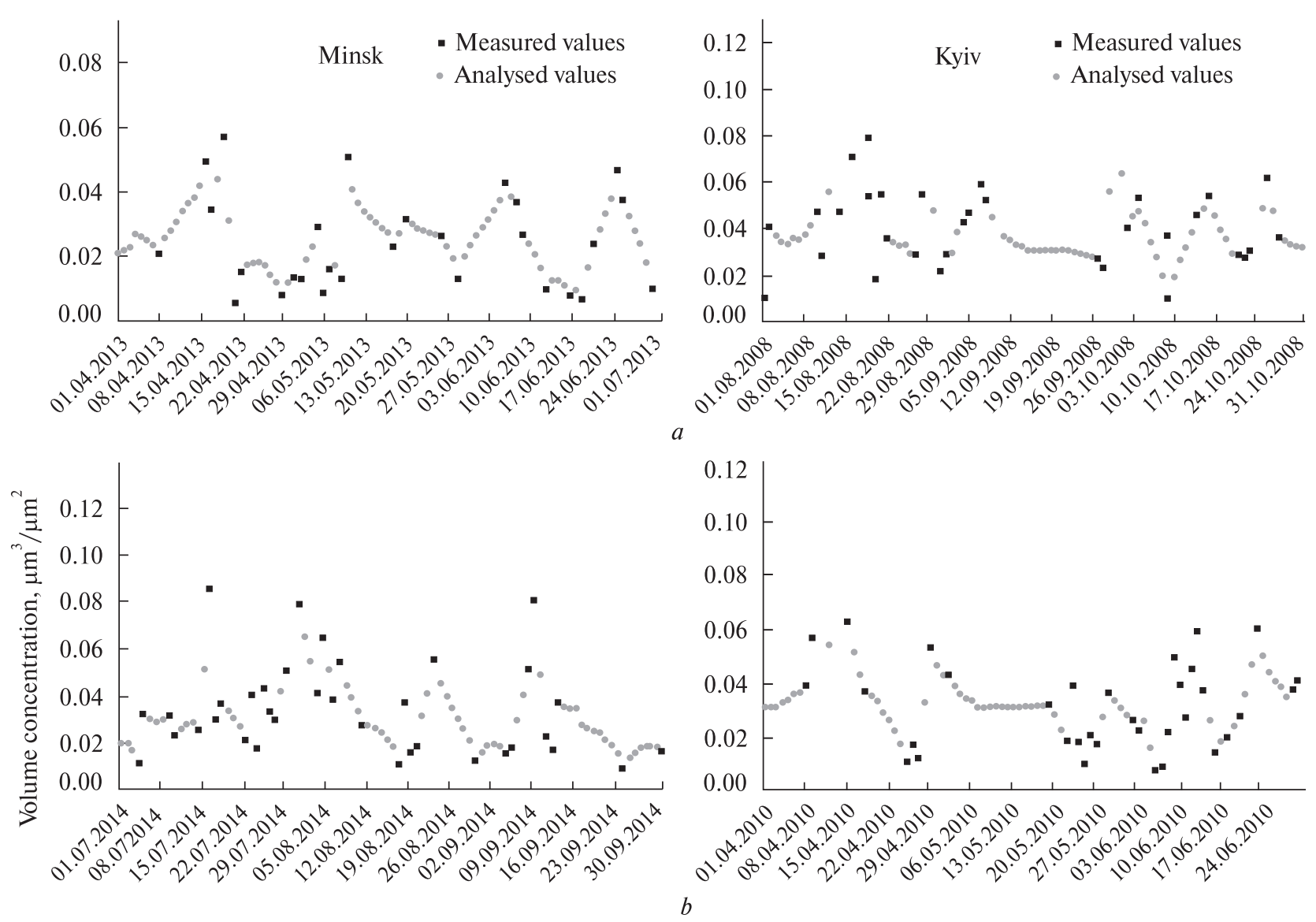

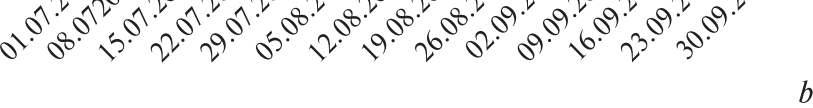
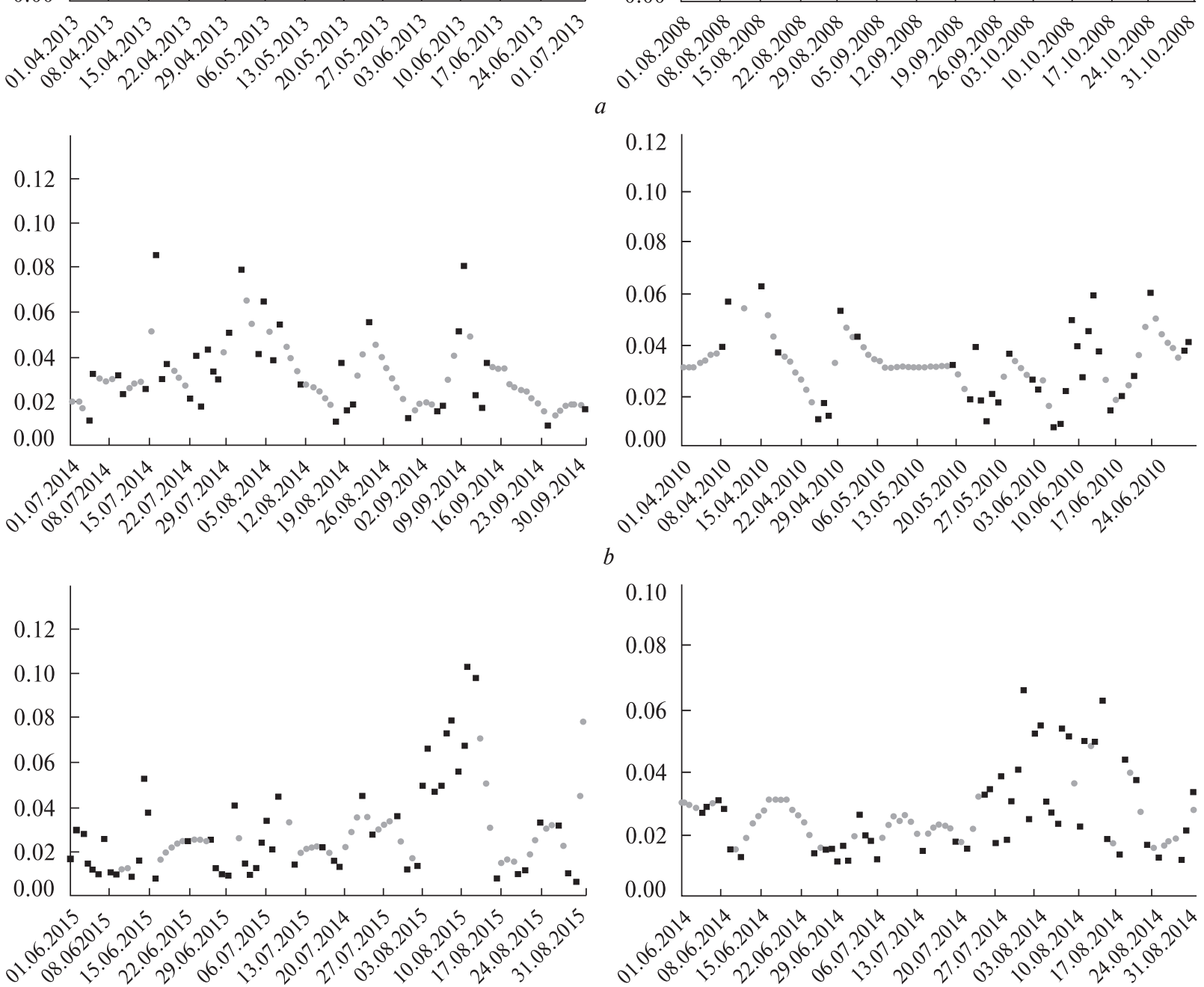

Date

Fig. 3. Results of implementation of optimal interpolation for the fine aerosol volume concentration at Minsk site: $a-$ AprilJune 2013, $b$ - July-September 2014, $c$ - June-August 2015, and Kyiv site: $a$ - August-October 2008, $b$ - April-June 2010, $c$ - June-August 2014 
tion that we use to obtain correlation function. We define background as the mean volume concentration averaged over 2002-2016 for Minsk site and 2008-2015 for Kyiv site, assuming stationarity. Fig. 2 shows the normalized, smoothed time interval dependence of the observation minus background correlation with the correlation interval 14 days for Minsk site and 8 days for Kyiv AERONET sites.

However, the weight matrix is not time invariant, because the observation points are distributed unevenly in time, so we have to calculate a new weight coefficients for every grid point. We restrict the observations used for each grid point to those observations which are within the correlation interval. Once weight coefficients have been calculated, the analyzed value of volume concentration at the grid point may be determined from (1).

Fig. 3 shows example of the implementation results of optimal interpolation for the fine aerosol volume concentration at Minsk and Kyiv sites in several periods of observation.

An optimal averaging method for AERONET data can be proposed on the basis of the temporal optimal interpolation method. Monthly mean AERONET data are often used for comparisons with results of satellite observations and model simulations. In AERONET, monthly mean is computed using the daily averages available in the month [18]. This averaging scheme implies that when observations are not available in some day, the volume concentration in this day is taken equal to monthly mean values computed from the available daily averages. It is obvious that this assumption is not optimal. We propose to use optimal interpolation method to calculate values of volume concentration in the days when observations are not available, and use the calculated values to obtain monthly mean.

\section{CONCLUSIONS}

Comparison of the aerosol volume concentrations simulated by chemical transport model GEOS-Chem and data retrieved from observations at AERONET sites shows that the model captures the magnitude and seasonal cycle of the monthly mean fine, coarse and total aerosol burden. However, the agreement between model results and measurements is not good enough for direct use of the model data for aerosol satellite measurements validation in the future Ukraine space project Aerosol-UA. To improve the fidelity of the aerosol simulation, an optimal interpolation method can be proposed for AERONET data assimilation in GEOS-Chem model. Implementation of the optimal interpolation method makes it possible to estimate the values of the aerosol volume concentration when measurements are not available. An optimal averaging method for AERONET data can be proposed on the basis of the temporal optimal interpolation method.

We acknowledge support by the Belarusian Republican Foundation for Fundamental Research (project X16K-042) and by the Ukrainian State Fund for Fundamental Research (grant F73/36-2017). The work was partly supported by the Special Complex Program for Space Research 2012-2017 of the National Academy of Sciences of Ukraine, and by the projects 16BF051-02 and 16BF023-01 of the Taras Shevchenko National University of Kyiv.

\section{REFERENCES}

1. Milinevsky G., Yatskiv Ya., Degtyaryov O., et al. Remote sensing of aerosol in the terrestrial atmosphere from space: new missions. Advs in Astron. and Space Phys., 5, 11-16 (2015).

2. Milinevsky G., Yatskiv Ya., Degtyaryov O., et al. New satellite project Aerosol-UA: Remote sensing of aerosols in the terrestrial atmosphere. Acta Astronautica, 123, 292-300 (2016).

3. Sica R. J., Izawa M. R. M., Walker K. A., et al. Validation of the Atmospheric Chemistry Experiment (ACE) version 2.2 temperature using ground-based and space-borne measurements. Atmospheric Chemistry and Phys., 8, 3562 (2008).

4. Ionov D. V., Timofeyev Y. M., Sinyakov V. P., et al. Groundbased validation of EOS-Aura OMI NO2 vertical column data in the midlatitude mountain ranges of Tien Shan (Kyrgyzstan) and Alps (France). J. Geophys. Res., 113, D15S08 (2008). doi:10.1029/2007JD008659.

5. Brogniez C., Auriol F., Deroo C., et al. Validation of satellite-based noontime UVI with NDACC groundbased instruments: influence of topography, environment and satellite overpass time. Atmos. Chem. Phys., 16, 15049-15074 (2016). doi:10.5194/acp-16-15049-2016.

6. Holben B. N., Eck T. F., Slutsker I., et al. AERONET - A federated instrument network and data archive for aerosol characterization. Remote Sens. Environ., 66, 1-16 (1998). 
7. Holben B. N., Tanre D., Smirnov A., et al. An emerging ground-based aerosol climatology: Aerosol optical depth from AERONET. J. Geophys. Res.: Atmospheres, 106, 12067-12097 (2001).

8. Milinevsky G., Danylevsky V., Bovchaliuk V., et al. Aerosol seasonal variations over urban sites in Ukraine and Belarus according to AERONET and POLDER measurements. Atmospheric Measurements Techniques, 7 (N 5), 14591474 (2014). doi:10.5194/amt-7-1459-2014.

9. Bovchaliuk A., Milinevsky G., Danylevsky $V$., et al. Variability of aerosol properties over Eastern Europe observed from ground and satellites in the period from 2003 to 2011. Atmospheric Chemistry and Physics, 13 (N 13), 6587-6602 (2013).

10. Dubovik O., King M. D. A flexible inversion algorithm for retrieval of aerosol optical properties from Sun and sky radiance measurements. J. Geophys. Res., 105(D16), 20673-20696 (2000). doi: 10.1029/2000JD900282.

11. Miatselskaya N., Kabashnikov V., Milinevsky G., et al. Atmospheric aerosol distribution in the Belarus-Ukraine region by the GEOS-Chem model and AERONET measurements, International J. Remote Sensing, 37:14, 3181-3195 (2016). http://dx.doi.org/10.1080/01431161.2 016.1194541

12. Molod A., Takacs L., Suarez M., et al. The GEOS-5 Atmospheric General Circulation Model: Mean Climate and Development from MERRA to Fortuna. Technical Report Series on Global Modeling and Data Assimilation, 28 (2012).

13. Bey I., Jacob D. J., Yantosca R. M., et al. Global modeling of tropospheric chemistry with assimilated meteorology: Model description and evaluation. J. Geophys. Res., 106 (D19), 23073-23095 (2001). doi: 10.1029/2001JD000807.

14. Martin R. V., Jacob D. J., Yantosca R. M., et al. Global and regional decreases in tropospheric oxidants from photochemical effects of aerosols. J. Geophys. Res: Atmospheres (1984-2012), 108(D3). ACH 6-1-ACH 6-9 (2003). doi: 10.1029/2002JD002622.

15. Gandin L. S. Objective analysis of meteorological fields. (Israel Program for Scientific Trans.), (Gidrometeorologicheskoe Izdatelstvo, Leningrad, 1963).

16. Lorenc A. C. Analysis methods for numerical weather prediction. Quart. J. R. Met. Soc., 112, 1177-1194 (1986).

17. Zhang, X. F., Heemink, A. W., van Eijkeren, J. C. H. Data assimilation in transport models. Appl. Math. Modelling, 21, 2-14 (1997).
18. Smirnov A., Holben B. N., Eck T. F., et al. Cloud-screening and Quality Control Algorithms for the AERONET Database. Remote Sens. Environ., 73, 337-349 (2000).

Received 22.05.17

Н. С. Метельська ${ }^{1}$, В. П. Кабашников ${ }^{1}$, А. В. Норко ${ }^{1}$, А. П. Чайковський ${ }^{1}$, А. І. Бриль ${ }^{1}$, Г. П. Міліневський ${ }^{2,3,4}$, В. О. Данилевський ${ }^{2}$

${ }^{1}$ Інститут фізики Національної академії наук Білорусі, Мінськ, Білорусь

${ }^{2}$ Київський національний університет імені Тараса Шевченка, Київ, Україна

${ }^{3}$ Головна астрономічна обсерваторія Національної академії наук України, Київ, Україна

${ }^{4}$ Цзилінський університет, Міжнародний центр науки майбутнього, Чанчунь, Китай

\section{МОДЕЛЮВАННЯ ВМІСТУ АЕРОЗОЛЮ В АТМОСФЕРІ ЗА ДОПОМОГОЮ МОДЕЛІ GEOS-CHЕМ ДЛЯ ВАЛІДАЦІЇ КОСМІЧНОГО ПРОЕКТУ «АЕРОЗОЛЬ-UА»}

В рамках глобальної хіміко-транспортної моделі GEOSChem розраховано розподіл середньомісячної об'ємної концентрації аерозолю і його дрібнодисперсної і крупнодисперсної фракцій для Мінська і Києва за період 2010-2015 рр. Результати модельних розрахунків зіставлено з вимірами на станціях наземної фотометричної мережі AERONET. Показано, що збіг є задовільним, але недостатнім для валідації супутникових вимірювань майбутнього проекту «Аерозоль-UA» за допомогою результатів моделювання. Для підвищення точності оцінки просторово-часового розподілу об'ємної концентрації аерозолю пропонується використати асиміляцію вимірювань мережі AERONET у модель GEOS-Chem на основі методу оптимальної інтерполяції. Побудовано тимчасову кореляційну функцію для об'ємної концентрації дрібнодисперсної фракції аерозолю за даними вимірювань на станціях AERONET Мінськ за період 2002-2015 pp. та Київ за період 2008-2015 pp. На основі методу оптимальної інтерполяції отримано оцінки об'ємної концентрації дрібнодисперсної фракції аерозолю для усіх точок тимчасової шкали. Запропоновано метод оптимального усереднення даних вимірювань мережі AERONET на основі тимчасового методу оптимальної інтерполяції.

Ключові слова: аерозоль, хіміко-транспортна модель GEOS-Chem, асиміляція даних, сонячний фотометр. 
Н. С. Метельская ${ }^{1}$, В. П. Кабашников ${ }^{1}$,

А. В. Норко ${ }^{1}$, А. П. Чайковский ${ }^{1}$, А. И. Бриль ${ }^{1}$, Г. П. Милиневский $2,3,4$, В. А. Данилевский ${ }^{2}$

${ }^{1}$ Институт физики Национальной академии наук Беларуси, Минск, Беларусь

2 Киевский национальный университет имени Тараса Шевченко, Киев, Украина

${ }^{3}$ Главная астрономическая обсерватория Национальной академии наук Украины, Киев, Украина

${ }^{4}$ Цзилинский университет, Международный центр науки будущего, Чанчунь, Китай

МОДЕЛИРОВАНИЕ СОДЕРЖАНИЯ АЭРОЗОЛЯ В АТМОСФЕРЕ С ПОМОЩЬЮ МОДЕЛИ GEOS-CHЕM ДЛЯ ВАЛИДАЦИИ КОСМИЧЕСКОГО ПРОЕКТА «АЭРОЗОЛЬ-UА»

В рамках глобальной химико-транспортной модели GEOS-Chem рассчитаны распределения среднемесячной объёмной концентрации аэрозоля и его мелкодисперсной и крупнодисперсной фракций для Минска и Киева за период 2010-2015 гг. Результаты модельных расчётов сопоставлены с измерениями на станциях на- земной фотометрической сети AERONET. Показано, что совпадение является удовлетворительным, но недостаточным для валидации спутниковых измерений в будущем проекте «Аэрозоль-UА» с помощью результатов моделирования. Для повышения точности оценки пространственно-временного распределения объёмной концентрации аэрозоля предлагается использовать ассимиляцию данных измерений сети AERONET в модель GEOS-Chem на основе метода оптимальной интерполяции. Построена временная корреляционная функция для объёмной концентрации мелкодисперсной фракции аэрозоля по данным измерений на станциях AERONET Минск за период 2002-2015 гг. и Киев за период 20082015 гг. На основе метода оптимальной интерполяции получены оценки объёмной концентрации мелкодисперсной фракции аэрозоля для всех точек временной шкалы. Предложен метод оптимального усреднения данных измерений сети AERONET на основе временного метода оптимальной интерполяции.

Ключевые слова: аэрозоль, химико-транспортная модель GEOS-Chem, ассимиляция данных, солнечный фотометр. 